\title{
Vepsän mailla Herran vuonna 2014
}

Koneen Säätion kieliohjelman rahoittaman hankkeemme Itämerensuomalaisten kielten muutos monikielisessä ympäristöss ä - jonka tuloksiin käsillä oleva julkaisukin kuuluu - tavoitteisiin kuului jatkaa Helsingin yliopiston tutkijayhteisön vepsän kielen puhujien keskuuteen tekemiä kenttätyöretkiä (näistä ks. Puura 2006). Teimme näistä lähtökohdista kesä-heinäkuussa 2014 matkan vepsäläisalueille. Hankkeemme vetäjä, itämerensuomalaisten kielten professori Riho Grünthal ja Helsingissä opintonsa aloittanut ja sittemmin oululaistunut Heini Karjalainen ajoivat vepsäläisalueelle Petroskoin kautta, jossa Grünthal oli ollut konferenssin kutsupuhujana. Minä matkustin muiden sitoumusteni vuoksi yksin rautateitse Pietarin kautta Babajevoon, josta muu seurue minut haki. Helsingistä vuokratun auton takakontti oli täynnä vepsänkielisiä julkaisuja puhujille jaettaviksi.

Matkamme suuntautui ensinnä Vologdan läänin Babajevon kuntaan, jossa kukaan meistä ei ollut aiemmin käynyt. Kylät, joissa Vologdassa vierailimme, olivat Päžar' sekä kaikkein itäisimmät vepsäläiskylät Pondal ja Voilaht. Näissä kylissä matkaseurueeseemme kuului myös Irina Sotnikova, vepsäläisen kuukausittain ilmestyvän Kodima-lehden päätoimittaja ja Petroskoissa opiskellut syntyperäinen pohjoisvepsäläinen. Hän oli tuonut vepsäläisille vepsänkielisiä lehtiä, ja koska hän halusi edistää lasten lukutaitoa, hän järjestikin Päžar'issa lukusession paikallisille lapsille. Sotnikova myös kirjoitti vepsäksi matkastamme jutun toimittamaansa lehteen (Sotnikova 2014). Loppuajan vietimme Leningradin läänissä Podporožjen kunnassa Ladvan kylässä, josta kävimme myös Mäggär'ven kylässä. Kylien sijainti on nähtävissä vepsän puhuma-alueen kartasta, joka tässä julkaisussa on painettu Heini Karjalaisen artikkeliin (Karjalainen 2019: 59).

1. Kiitän Riho Grünthalia, Heini Karjalaista, Ulriikka Puuraa ja Saarni Laitista raporttini kommentoinnista. 
Kielitieteellisestä työstä ja kielenoppaista

Riho Grünthal jatkoi aiempia tutkimuksiaan keräämällä sopivilta kielenoppailta itselleen mieluista aihetta, verbiparadigmoja, sekä varmisti nominien paradigmoja, muutoin mitä milloinkin sai. Oli kiinnostavaa huomata, että oppaat eivät kuitenkaan millään tuottaneet perfektimuotoja, vaan perfektin funktiossa käytettiin imperfektiä. Grünthal on julkaissut tältä ja muilta matkoiltaan keräämäänsä aineistoa Vepsän kieliopissa (Grünthal 2015). Hauskimpiin haastatteluihin kuuluivat ne, jotka tehtiin erään keski-ikäisen pariskunnan kanssa. Heistä toinen, Aleksander Mednikov, oli kotoisin Pondalasta, toinen, Pondalan museonjohtaja Vera Mednikova, puolestaan Voilahdesta. Heillä oli tapana hymy suupielessä mainita, että toisen antama muoto oli vallankin väärä ja kertoa, kuinka sama asia heidän omassa kotikylässään sanottiin. Nämä kielenoppaat olivatkin poikkeuksellisen tietoisia kielestään. Vanhin kielenoppaamme, Maria Triškina, oli vuonna 1927 syntynyt Päžar'in Jušmäellä samaan taloon, pert'he, jossa hän edelleen nyt jo kylänsä vanhimpana eli. Hän oli mennyt kouluun vuonna 1934, jolloin vepsän kielellä alettiin opettaa, ja osasi lukea ja kirjoittaa vepsää sekä pystyi edelleen laskemaan vepsäksi. Se on hyvin harvinaista, sillä sujuvankin vepsän puhujat tapaavat vaihtaa venäjän koodiin juuri numeraaleja käytettäessä.

Heini Karjalainen, jonka väitöskirjan tekoa Koneen Säätiö rahoitti neljän vuoden ajan, keräsi aineistoa väitöskirjaa varten. Karjalaisen kenttätyö liittyi ensisijaisesti hänen laatimaansa indefiniittipronomineja käsittelevään kyselykaavakkeistoon, nk. elisitaatiotestiin, jota hän kävi läpi yhdessä kielenoppaiden kanssa. Karjalainen luki kielenoppaille esimerkkilauseensa ja mahdolliset pronominit, joilla lauseet voisi täydentää. Tiivis yhteistyö olikin tarpeen, sillä välillä oppaille oli aihetta selittää mitä heiltä toivottiin. Yhtäältä latinalaisten kirjainten lukeminen ei olisi kaikilta sujunut, toisaalta aivan kaikki kielenoppaat, joiden kanssa kyselyä tehtiin, eivät välttämättä heti oikein tavoittaneet kyselyn ideaa. Haastateltavien kanssa päästiin kuitenkin aina yhteisymmärrykseen, ja he antoivat keskustelujen aikana paljon hyviä kommentteja eri vaihtoehdoista. Näiden haastattelujen tuloksia on sekä tässä julkaisussa Karjalaisen artikkelissa Borrowing morphology (Karjalainen 2019) että hänen vepsän kielen 
indefiniittipronominien järjestelmää käsittelevässä artikkeliväitöskirjassaan (Karjalainen 2016).

Minä olin matkalla oppimassa. Hankkeessamme ennen minua reilun puoli vuotta työskennellyt ja useilla aikaisemmilla Vepsänmatkoilla kenttätöitä tehnyt Ulriikka Puura väitteli sittemmin vepsäläisestä kieliyhteisöstä (Puura 2019), mutta omat tutkimuskohteeni eivät ainakaan vielä ole liittyneet vepsään saati itse kerättyyn kenttäaineistoon. Kuunteluoppilaana kirjoitin muistiinpanoja korva tarkkana ja äänitin kaiken siinä missä muutkin. Joitakin haastatteluja videoin. Puhutusta vepsästä kiinni saaminen vei oman aikansa, sillä vepsän kielen kursseilla opitun lisäksi venäjän taitoa olisi selvästi tarvinnut alkeiskurssia laajemmin. Lähes kaikilla puhujilla tapahtuva toistuva koodinvaihto venäjään aiheutti minulle päänvaivaa. Koodinvaihtoa tapahtui jatkuvasti siitäkin huolimatta, että puhujat tiesivät kielirajoitteestani. Tämä johtui todennäköisesti siitä, että puhujilla, jotka eivät ole olleet tekemisissä standardivepsän kanssa, ei välttämättä omassa idiolektissaan ole olemassa kategorioita "vepsä" ja "venäjä". ${ }^{2}$ Onpa tunnustettava, että matkamme alussa venäjän aksentilla lausuttuihin vepsänkielisiin tervetulotoivotuksiin tulin koko päivän matkustamisesta väsyneenä vastanneeksi, etten puhu venäjää.

Kuuntelemiseen harjaantuessa korvaan tarttui kuitenkin leksikaalisiakin eroja: Voilahdessa parillakin kielenoppaalla esiintyi hond 'huono', kun kylävepsässä tavallisempi adjektiivi on huba. Päžar'issa samanmerkityksisen sanan komparatiivi oli honomb.

Kaikki majoittajamme toimivat myös kielenoppainamme. Päžar'issa meidät majoittivat opettaja Olga Smirnovan vanhemmat Nina Fomina ja Nikolai Fomin. Olga Nikolajevna itse kiersi mukanamme näyttämässä meille paikkoja, tutustuttamassa ihmisiin ja auttamassa haastatteluissakin. Kotona meidät ruokittiin muun muassa erilaisilla itse paistetuilla herkullisilla piirakoilla, joita oli aina runsaasti. Niitä riitti myös Pondalassa, jossa Vera Mednikova oli järjestänyt emännäksemme Galina Serdtsovan. Hän asuu perinteistä vepsäläistaloaan kesäisin ja viettää talvet kaupungissa. Kaikissa paikoissa kaikilla aterioilla tarjottiin ruokajuomana teetä ja perusruoka-aineksiin kuului keitetty tattari, jossa rasvaa ei säästelty.

2. Kiitos Ulriikka Puuralle tästä huomiosta. 

VEPSÄN MAILLA HERRAN VUONNA 2014

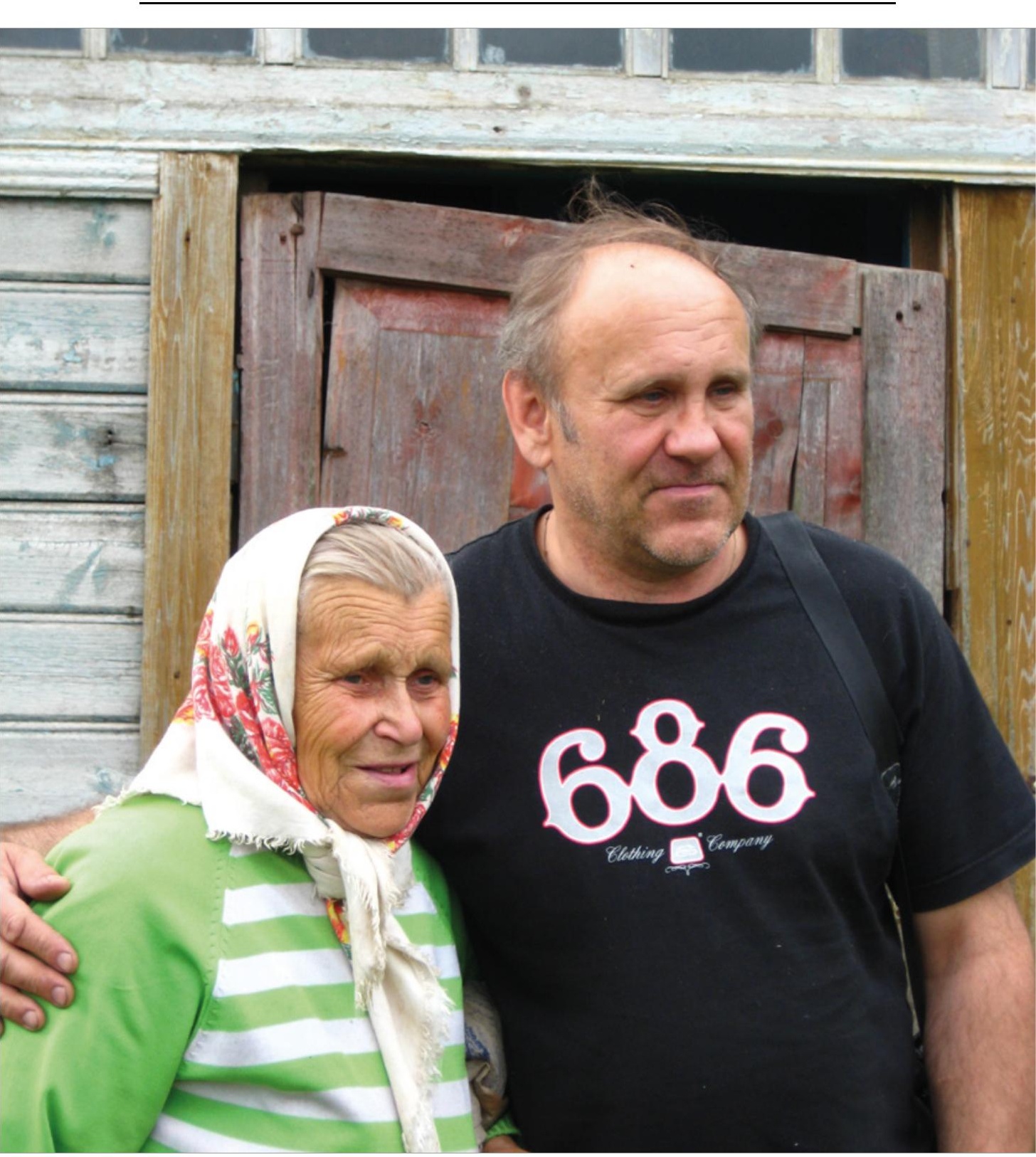

Kuva 2. Maria Abramova ja Nikolai Abramov. Kuva: Sofia Björklöf. 


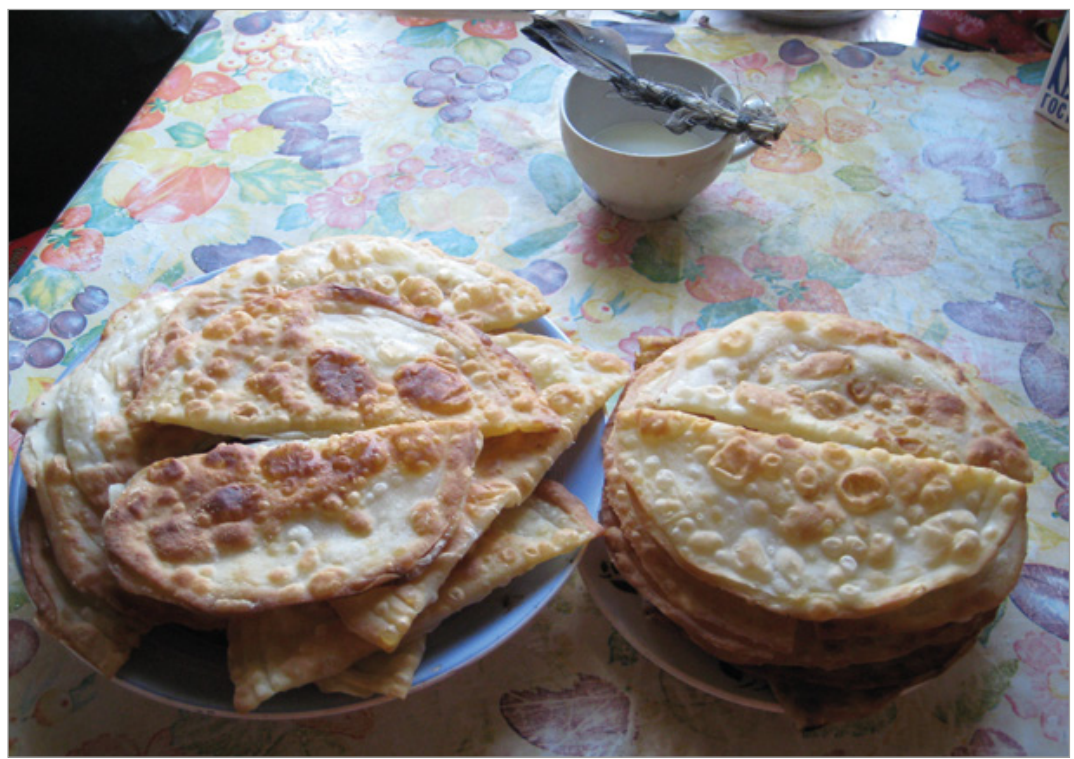

Kuva 3. Piirakat ja linnunsulkasivellin. Kuva: Sofia Björklöf.

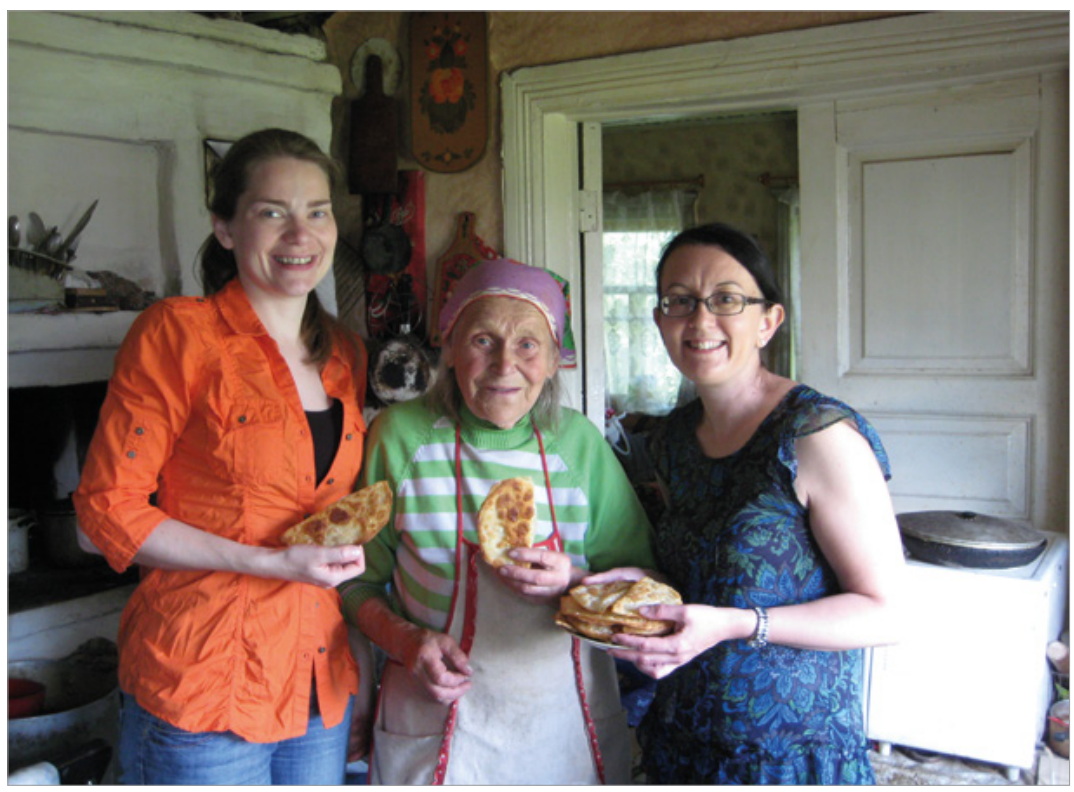

Kuva 4. Piirakanpaistajat Sofia Björklöf, Maria Abramova ja Heini Karjalainen. Kuva: Nikolai Abramov. 
Paikallisia kuriositeetteja

Matkalla riitti kommelluksiakin. Mieliimme lienee parhaiten jäänyt, kuinka professori Grünthal yritti keskustella sonnin kanssa sillä tuloksella, että jouduimme miltei eläimen hyökkäyksen kohteeksi. Vähäinen karja kulkee vielä Päžar'in kylänraitilla ajettuna ja niityillä vapaina. Sievistä lehmistä ja vasikoista ei juuri harmia ole, mutta kulkureitillämme oleili pari sonnia lehmineen, joita ensinmainittujen tietysti oli suojeltava. Eräänä päivänä kulkiessamme kylän toiseen päähän haastatteluja tekemään sonni ja lehmät sattuivat olemaan reitillämme. Sonneista ei arvaa kovin läheltä ohi mennä, joten jäimme odottelemaan niiden liikkumista tieltämme. Toinen sonni alkoi vaikuttaa meistä hieman kiinnostuneelta, ja oli virhe sanoa sille matalalla miehen äänellä "muu". Tästäkös sonni pahastui ja kukapa tietää, minkä solvauksen professori sille tuli esittäneeksi. Eläimen käytös muuttui ja se alkoi lähestyä meitä. Paikka oli täysin aukea: ainoa pelastuksemme oli vain muutaman kymmenen metrin päässä sijainnut luhistumaisillaan oleva katos, jonka suojiin hakeuduimme. Suurempaa hyökkäystä barrikadimme ei olisi kestänyt, sillä sen päälle kiipeäminen olisi ollut paitsi turhaa myös vaarallista. Tämän kohtaamisen jälkeen kuljimme kyläteillä kirjaimelliset kättäpidemmät, karahkat, käsissämme.

Elämä vepsäläiskylissä on edelleen monin osin kuin suomalaisella maaseudulla ennen viime sotia. Heinä kuivatetaan edelleen haasioissa ja nostetaan sen jälkeen heinäsuoviin (kuva 5), joita molempia näimme Päžar'issa useita. Pyykkiä pestään ja huuhdotaan joissa (kuva 6) ja kylpeminen tapahtuu luonnollisesti saunoissa, jotka perinteisimmillään sijaitsevat rivissä joen rannalla (kuva 7). Jos külbet on kovin kuumaksi lämmitetty, ei parane nautiskella löylyistä turhan pitkään ennen kuin aloittaa pitkien hiusten pesemisen, mikäli haluaa välttyä huonovointisuudelta, sillä - kuten suomalaiset hyvin tietävät vanhassa rakennustyypissä peseytyminen tapahtuu löylyhuoneessa. Pesuvesi lämmitetään kiukaan yhteyteen rakennetussa padassa. Kyläkaupassa ostosten summa lasketaan nopein sormin helmitaululla (kuva 8). Päžar'issa Fominin perheen venevajassa taas oli isännän itsensä rakentama soutuvene (kuva 9) ja verkkojen kohot olivat koivuntuohta (kuva 10). 


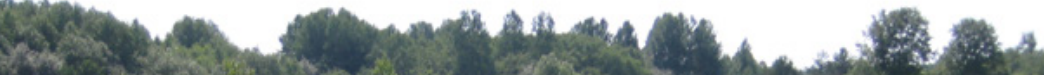

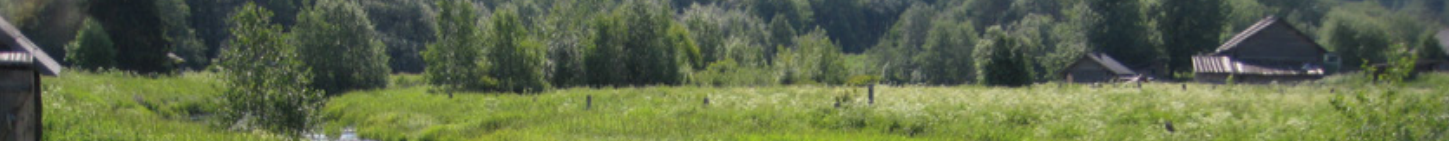

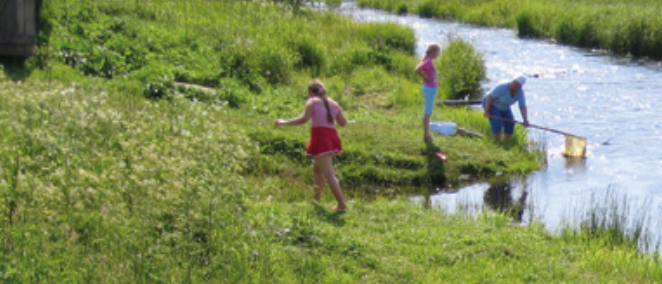

1.

(1) 

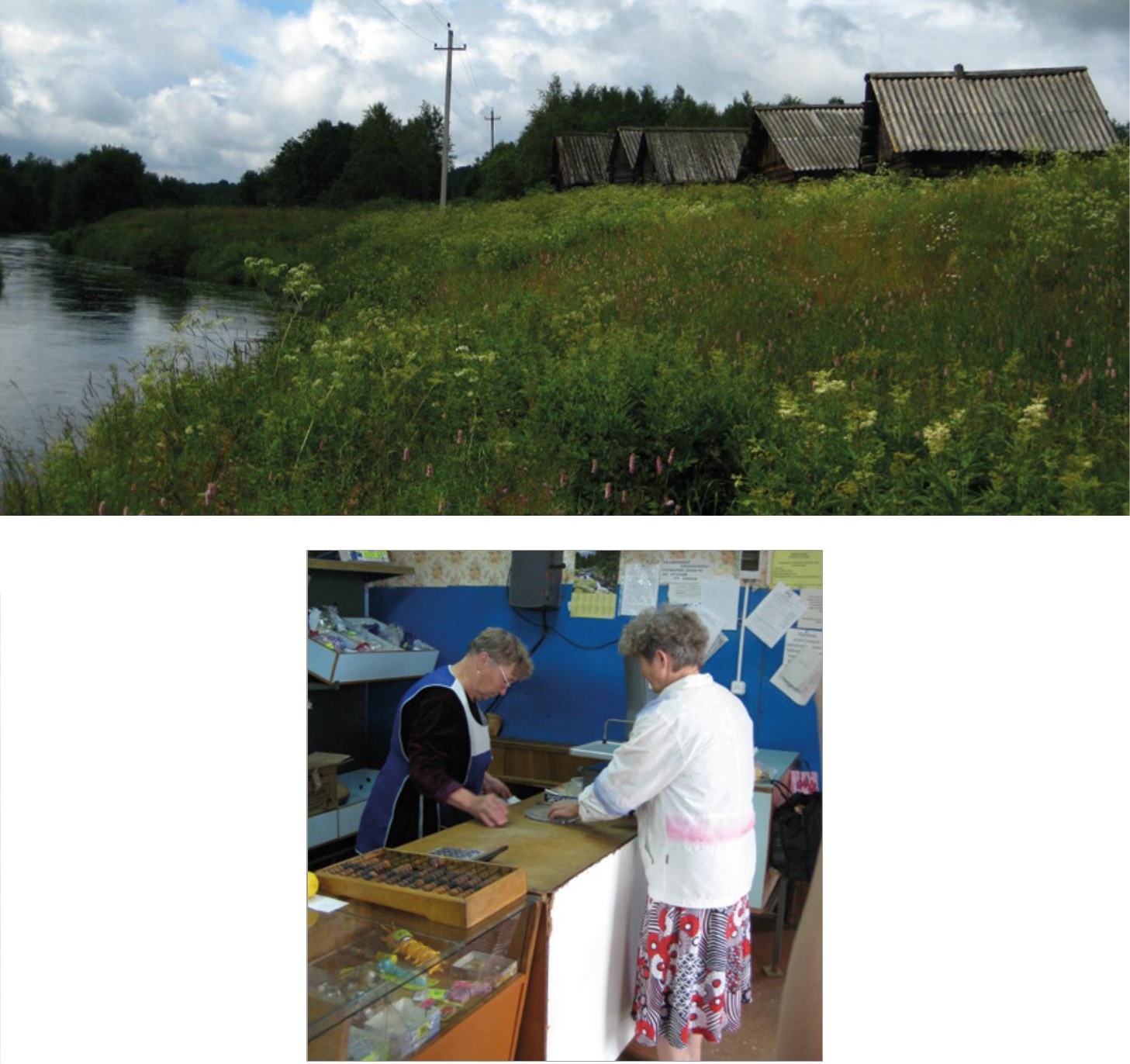

Kuva 5 (vas. ylh.): Heinäsuova ja matala haasia Päzar'issa. Kuva 6 (vas. alh.): Pyykin huuhtomista Pondalassa. Kuva 7 (oik. ylh.): Saunat Ladvassa. Kuva 8 (oik. alh.): Vepsänkielistä asiointia Pondalan kaupassa. Helmitaulu etualalla, asiakkaana Vera Mednikova. Kuvat: Sofia Björklöf. 


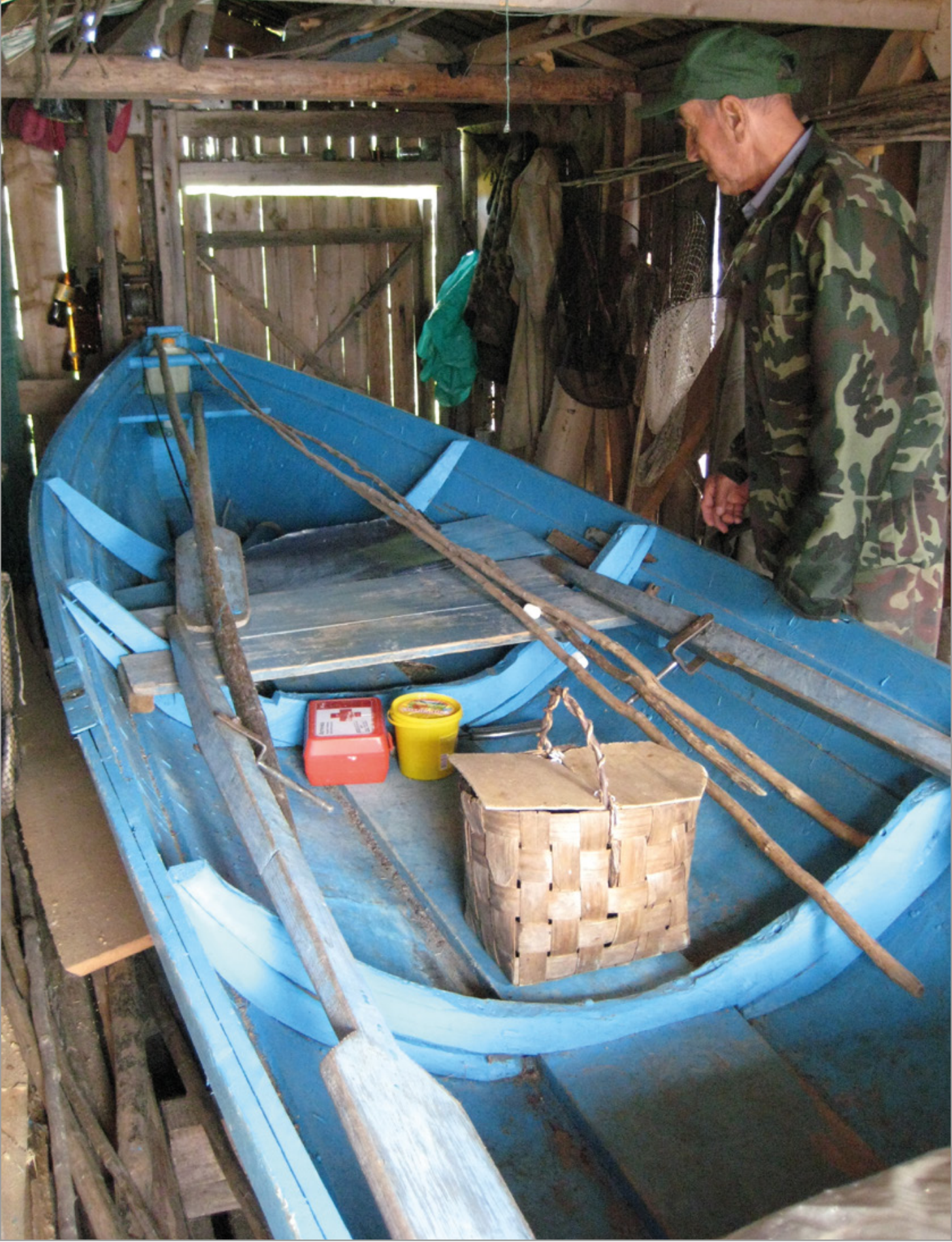


talosta pitäisi saada, jos metallista mielisi. Lienimmekö muotivirtauksen henkisiä edelläkävijöitä, sillä vuonna 2016 hieman erilaisella mekanismilla toimivia metalliversioita oli tarjolla Suomen tavarataloissa.

Olin viisi vuotta aikaisemmin ollut suomalais-ugrilaisen kielentutkimuksen määräaikaisen professorin Janne Saarikiven johtamalla kenttätyökurssilla Tverin Karjalassa, lukenut ja kuullut matkakertomuksia. Silti en välillä voinut olla ihmettelemättä, miten paljon voi Venäjän maaseudulla (huonokuntoista) tietä riittää. Kartalla lyhyehköltäkin näyttävän hiekkatien ajaminen voi kestää pitkään, sillä joitakin teitä ajavat jatkuvasti raskaat puutavaraa kuljettavat rekat ja tiestö on kauttaaltaan suurilla, syvillä kuopilla. Ajo tällaisella tiellä onkin tarkkaa puuhaa, kun kuoppia pitää parhaansa mukaan kierrellä. Alkuun vain tunnin ajomatka keinutti tottumatonta vielä seuraavanakin aamuna kuin olisi merenkäynnissä ollut. Kolmen ajokortillisen seurue helpottaa myös matkantekoa huomattavasti, kun ajamista voi olla päivässä yhtä mittaa helposti kahdeksan tuntia. Vaikka taisinpa minä jonkin kerran sellaisen rupeaman innostua kerrallakin ajamaan. Matkapuhelinverkossakaan ei maaseudulla ole kehumista, ja kotiin soitetaan niin, että kiivetään kaikkein korkeimmille paikoille ja vielä niillä sijaitseviin pylväisiin tai tikapuille (kuva 11). Internet taas ei tule Vepsänmaalla mieleenkään.

\section{Kenttätyön käytäntöä ja tekniikkaa}

Kantapään kautta tunnetusti oppii, tällaisellakin matkalla. Sen tiesin, että nauhuriin on oltava mukana paljon uusia paristoja. Äänitystä aloitettaessa laitteessa olevien paristojen pitää mieluiten olla uudet ja äänittäviä nauhureita on hyvä olla useita; videokameran ääniraita ei korvaa erillistä nauhuria, vaikka onkin oiva lisä. Suomalais-ugrilaisen oppiaineemme kenttätyömatkoilla ei ollut videoitu järjestelmällisesti, ja videokameraa käyttäessäni tulin havainneeksi, että siihenkin pitäisi olla mukana useampia akkuja. Myös muistikortteja on oltava useita, sillä sen varaan ei missään nimessä pidä laskea, että ehtii tyhjentää korttia kannettavalle tietokoneelle. Tyhjentäminen ei kannata siksikään, että on sitä parempi, mitä useammalla tallennusvälineellä tiedostot ovat tallessa. Videotiedostot vaativat lisäksi paljon tallennustilaa, eikä niitä kannata kotioloissakaan turhaan yrittää tallentaa liian 


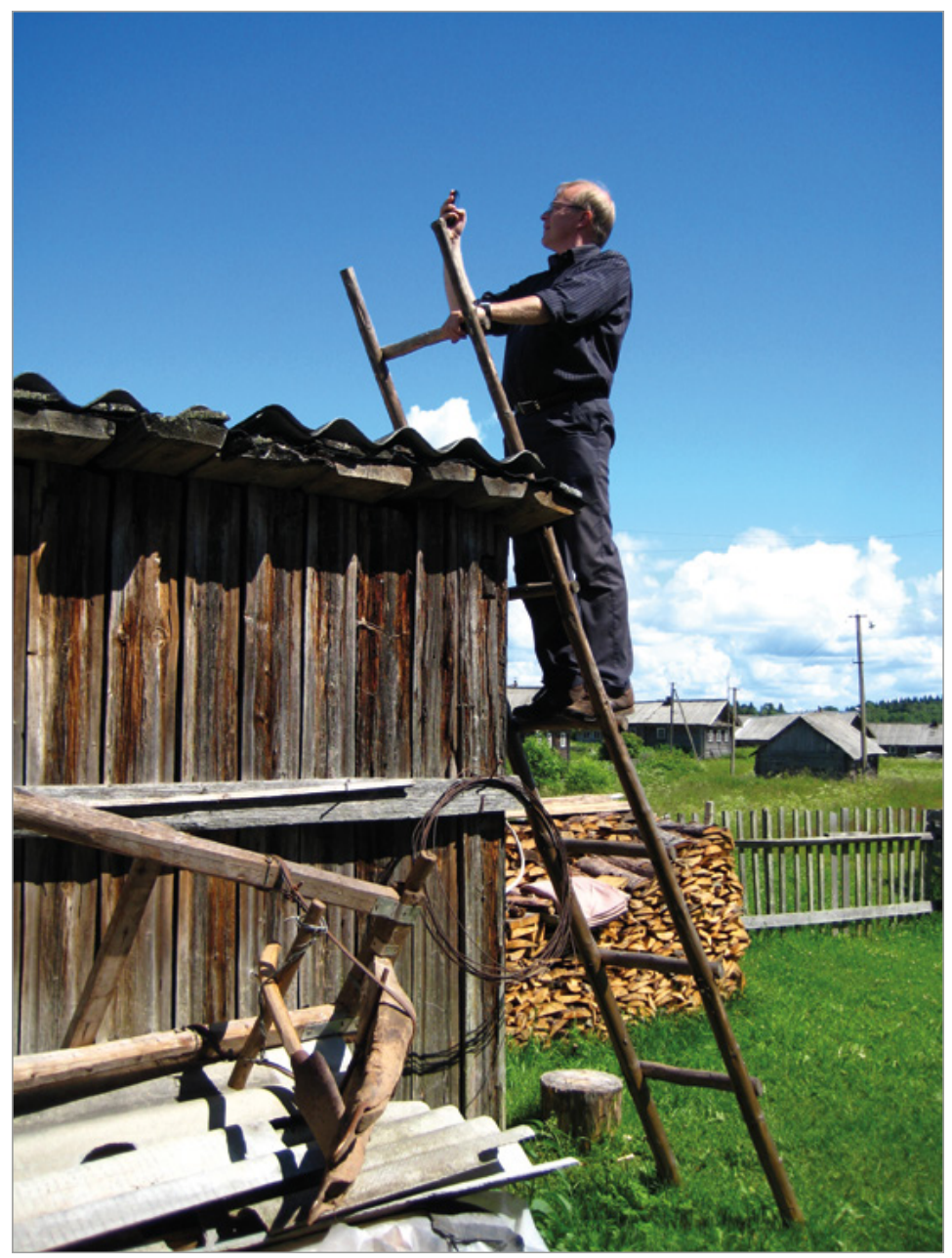

Kuva 11. Riho Grünthal Mäggär’vellä kenttää etsimässä. Kuvassa etuvasemmalla myös aura. Kuva: Sofia Björklöf.

pienille dvd-levyille. Tietokone myös tarvitsee säännöllisesti virtaa, jota kenttäolosuhteissa ei aina ole saatavilla. Videokameran kolmijalka on välttämätön, jotta kuva ei tärise ja kuvaaja pystyy käyttämään myös nauhuria sekä tekemään muistiinpanoja, mutta varusteisiimme se onneksi kuuluikin. Mutta vasta vuonna 2016 järjestetyssä Koneen 
Säätiön uralilaisten kielten dokumentaatiota, kuvaamista ja revitalisaatiota käsitelleessä kesäkoulussa opin Michael Rießleriltä, että Mikki Hiiri -mallisen nauhurin mikrofonien vaahtomuovisuojukset ovat itse asiassa ulkokäyttöön tarkoitetut ja ne pitää poistaa sisällä nauhoitettaessa. Haastatteluja tehdessä kannattaa myös muistaa kirjoittaa muistiinpanoja nauhoittamisesta huolimatta, sillä nauhoituksista on myöhemmin huomattavasti helpompi etsiä haluamiaan asioita, kun niiden metatiedot ja sisältöä on jo paperilla. Esimerkiksi paradigmat kannattaa niitä kyseltäessä kirjoittaa saman tien kokonaan. Samoin tuttu tapa tehdä nauhoituksen alkuun sanallinen muistiinpano sen osanottajista, paikasta ja päivämäärästä on edelleen tarpeen.

Kaikenlainen dokumentoiminen, siis valokuvaus ja päiväkirjan pitäminen kenttätyöretkellä ovat mitä suositeltavimpia harrasteita. Mitä enemmän jaksaa kirjoittaa tilanteista ja tunnelmista heti samana päivänä, sen enemmän päiväkirjasta on jälkeenpäin iloa ja hyötyä tutkimuksessakin. Asiat, jotka ajankohtaisina ja juuri tapahduttuaan tuntuvat aivan yksinkertaisilta tai itsestäänselviltä, unohtuvat kuitenkin yllättävän helposti ja nopeasti. Matkapäiväkirjaa pitikin jo itämerensuomen tutkimuksen saralla valtavan työn tehnyt Lauri Kettunen, jonka ensimmäisestä Vepsän-matkasta vuosina 1917-1918 voi lukea hänen muistelmateoksestaan Tieteen matkamiehenä (Kettunen 1945: 272-407). E. N. Setälän kanssa vuotta aiemmin vepsäläisalueen läpi matkannut etnomusikologi A. O. Väisänen on puolestaan julkaissut sanomalehdessä sarjan lyhyitä matkakertomuksia (Väisänen 1916).

\section{Matkan jälkeen}

Kotiin palattuaan vastuullinen tutkija luonnollisesti järjestää ja arkistoi kenttäsaaliinsa. Aineistosta myöhemmin syntyviä julkaisuja on hyvä aikanaan viedä alkulähteilleen: näin tutkija pystyy antamaan jotakin takaisin puhujayhteisölle, jolta itse sai materiaalia tutkimuksiinsa. Jakamalla julkaisuja kielenpuhujille voi paitsi kertoa tutkimustuloksistaan, myös osoittaa arvostustaan ja tukea kielellistä identiteettiä. Joissain tapauksissa pystytään myös tuottamaan esimerkiksi yleistajuista oppimateriaalia puhujayhteisön aktiiviseen käyttöön. Näitä seikkoja on osattu alkaa ajatella vasta viime aikoina. 
Kirjallisuutta

Abramov, Nikolai 1994: Koumekümne koume. Runokirj. Petroskoi: Karjala. Grünthal, Riho 2015: Vepsän kielioppi. Apuneuvoja suomalais-ugrilaisten kielten opintoja varten XVII. Helsinki: Suomalais-Ugrilainen Seura.

Karjalainen, Heini 2016: Yhteisöt kontaktissa, systeemit muutoksessa. Vepsän kielen indefiniittipronominien järjestelmä. [Väitöskirja.] Acta Universitatis Ouluensis B Humaniora 142. Oulu: Oulun yliopisto. Artikkeliväitöskirjan johdanto-osa saatavissa: 〈http://urn.fi/ urn:isbn:9789526212234>

2019: Borrowing morphology: The influence of Russian on the Veps system of indefinite pronouns. - Sofia Björklöf \& Santra Jantunen (eds), Multilingual Finnic. Language contact and change. Uralica Helsingiensia 14. Helsinki: Finno-Ugrian Society. 55-87. Saatavissa: 〈https://doi.org/10.33341/uh.85033〉

Kettunen, Lauri 1945: Tieteen matkamiehenä. Kaksitoista ensimmäistä retkeä 1907-1918. Helsinki: Werner Söderström osakeyhtiö.

Puura, Ulriikka 2006: Vepsäläinen kielikylpy. - Alkukoti 8: 38-41. [Helsingin yliopiston ylioppilaskunnan sukukansavaliokunnan lehti.] Saatavissa: 〈http://www.helsinki.fi/hyy/skv/alkukoti/alkukoti8www.pdf〉 2019: Sinä iče oled vepsläine, voib sanuda, ka? Vepsäläisyyden rakentuminen ja 2000-luvun vepsän kieli. [Väitöskirja.] Helsinki: Helsingin yliopisto. Artikkeliväitöskirjan johdanto-osa saatavissa: 〈http://urn.fi/ URN:ISBN:978-951-51-4878-0>

Sotnikova, Irina 2014: Matk vepsläižidennoks Vologdan agjaha. - Kodima, Reduku 2014 №10 (259): 4-5. Saatavissa: 〈http://kodima.rkperiodika. ru/wp-content/uploads/2015/02/Kodima_10_2014.pdf>

Väisänen, O[tto] 1916: Vepsän mailla. Matkamuistoja I-V. - Uusi Suometar 19.11., 21.11., 29.11., 7.12. ja ?.12.1916. [Saatavissa Helsingin yliopiston pääkirjastosta kopiosidoksena.] 